\title{
ИСТОРИОГРАФИЯ ИСТОРИИ ЗАРАЙСКА (ОТ ОСНОВАНИЯ ДО КОНЦА XVII В.): XX - XXI В.
}

\section{HISTORIOGRAPHY OF THE HISTORY OF ZARAYSK (FROM THE FOUNDATION TO THE END OF THE XVII CENTURY): $X X$ - XXI CENTURIES}

\section{A. Rodionov}

Summary: Zaraysk (Moscow region) concerns to the most ancient towns in the Central Russia. Its origin and formation is associated with the cult of the famous miracle-working icon of Nikola Zaraisk, it was taken there in 1225 according to the legend. There are many controversial issues in the early history of Zaraisk. The first mention of the town on the Osetr banks dates to 1146 , the town had the same name as the river - Osetr. This date is considered to be the date of Foundation by the authorities and the public. However, archaeological researches on the territory of the Zaraisk Kremlin show that the settlement appeared in the XVI century.

Only after the construction of the Kremlin in 1531 Zaraysk became a town. The article contains a synthesis and analysis of materials published on the history of the Moscow region town of Zaraysk and devoted to the issues of its Foundation and development until the end of the XVII century.

The researchers' most interesting problems are the date of the city's foundation (sources about it and the question of their reliability), the historicity of the cycle of stories about Nikola Zarazskiy (literary history and textual history), Zaraysk in the time of Troubles, the topography of the XVII century (Zaraysk was repeatedly rebuilt after fires.

Keywords: Zaraysk, Nikola Zaraisky, Osetr, a series of Stories about Nikola Zarazsky, local history, historiography, archaeology.
Родионов Александр Викторович

Аспирант, ГОУ ВО Московской области «Государственный социально-гуманитарный университет», г. Коломна

1979rav@mail.ru

Аннотация: Зарайск Московской области относится к числу древних летописных городов Центральной России. Его зарождение и становление связано с культом известной чудотворной иконы Николы Зарайского, согласно преданию, перенесенной туда в 1225 г. В ранней истории Зарайска существует немало спорных вопросов. Первое упоминание о городе на берегах реки Осетр относится к 1146 году (город носил одноименное с рекой название - 0сетр), который властью и общественностью считается датой основания. Однако, доказательств этому не имеется. Проведенные археологические изыскания на территории Зарайского Кремля ясно показывают, что городское поселение возникло в XVI веке.

0 Зарайске, как о городе, мы можем с полной уверенностью говорить лишь после строительства в нем Кремля в 1531 году.

Статья содержит обобщение и анализ материалов, вышедших по истории подмосковного города Зарайска и посвященных вопросам его основания и развития до конца XVII века.

Основными проблемами данного периода, интересовавшими исследователей, являются: дата основания города (источники о ней и вопрос их достоверности), историчность цикла повестей о Николе Заразском (литературная история и текстология), Зарайск в Смутное время; топография XVII века (Зарайск неоднократно перестраивался после пожаров).

Ключевые слова: Зарайск, Никола Зарайский, Осетр, цикл Повестей о Николе Заразском, краеведение, историография, археология.

рики рязанские исследователи считают историю Зарайска частью истории Московской области, в состав которой он входит в настоящий момент. Поэтому изучение истории Зарайска до определённого времени в большей степени было уделом краеведов.

Ставка на туристическое направление в развитии экономики города Зарайска, восстановление и реставрация памятников заставляют по-новому взглянуть на историю города, обратиться к его истокам, заполнить «белые» пятна в истории самого малого и полностью сохранившегося кирпичного кремля Подмосковья.

К сожалению, территория города Зарайска с точки зрения археологии изучена слабо. По мнению И.Е. Зайцевой, в настоящее время можно с уверенностью говорить только о существовании селища, возникшего на берегу реки Монастырка в XII в. и просуществовавшего до конца XIV в. Жизнь на поселении возобновляется только 
в конце XV в. [7, С.14]. Той же точки зрения придерживается и И.Ю. Стрикалов [19, С.29-30].

Поэтому основное внимание при изучении данной темы следует уделить письменным источникам и литературе. Основными источниками по наиболее раннему периоду истории являются Никоновская летопись и цикл «Повестей о Николе Заразском». Последний представляет собой свод литературных произведений, получивший окончательное оформление в XVI в.

В 20-30-ые годы разрабатывались новые методологические основы историографии, поэтому вопросами местной истории занимались краеведы.

В этом контексте неудивительно, что новым толчком в развитии историографии Зарайска стало основание Зарайского краеведческого музея. Его первым директором был Н.И. Перлов. Работа Н.И. Перлова дает подробное описание укреплений Зарайска в интересующий нас период с попыткой привязать их к современной застройке города. Одновременно Перлов дает предысторию вопроса, фактически связывая город Осетр с Зарайском $[17$, C.9].

Академические историки обращаются к истории Зарайска только в середине XX века.

Серьезной критике подверг известия, содержавшиеся в Никоновской летописи, А.Н. Насонов. Анализируя текст летописи, он пришел к выводу о ее недостоверности. Это касалось как самого похода Святослава Ольговича в 1146 году, так и упоминания шести городов в ней как рязанских земель, в том числе и Осетра. По мнению Насонова А.Н. «автор Никоновской летописи прибег к сочинительству» [16, С.189], с целью доказать в противостоянии с Литвой принадлежность земель к Рязани. Данные Никоновской летописи историк активно сравнивал с другими, особенно с Ипатьевской. Фактически мы можем говорить о первой серьезной попытке анализа сообщения Никоновской летописи о граде Осетре под 1146 годом.

Не менее критичных взглядов на цикл повестей о Николе Зарайском придерживалась и В.И. Антонова. В целом она поддержала идеи Н.И. Петрова. В.И. Антонова в своей работе провела анализ культа Николы Зарайского. Как и Н.И. Петров, она считает корсунский эпизод более поздней вставкой, связанный с «еще живым в то время традиционным восхищением культурой Византии» [3, С.379]. Обрусение Николы Зарайского привело к тому, что он стал почитаться как защитник русской земли. Но к концу XV века легенда о Николе Зарайском уступила свои позиции легенде о Николе Можайском. Присоединение Рязанских земель привело к ее реанимации и серьезным правкам [3, С.384]. Автор провела анализ иссле- дований икон Николы Зарайского: образ Николы Оранта получил свое название в честь Зарайска, как одной из самых старых икон. К сожалению, подлинник иконы был утрачен, и установить ее истинное происхождение невозможно. До нас дошел список 1513 г. В.И. Антонова Выявила хронологию икон Николы Зарайского и пришла к выводу, что наиболее древний образ - это икона 1303 года из Киевца, привезенная в Москву киевским боярином Романом Нестеровичем [3, С.376].

М.Н. Тихомиров в своей работе «Список городов дальних и ближних», полагая, что список был составлен в 1387-1392 гг. [20, C.88], не дает четкого ответа о месте нахождения Нового горока на Осетре. Вначале он ассоциирует его с Зарайском, но тут же оговаривается, что это может быть и село Городна [20, С.119-120].

Вышедшая в середине XX века работа А.Л. Монгайта должна была объединить данные по археологическим изысканиям. Автор приходит к выводу, что располагающиеся вокруг Зарайска курганы следует отнести к вятическим, и датирует их XII-XIV веками [15, С.130]. Наличие в округе города большого количества памятников данного периода позволяет, по мысли автора, предположить о существовании Зарайска уже в XII веке [15, С.238]. При этом маршрут движения Святослава Ольговича в 1146 году А.Л. Монгайт считает не соответствующим действительности [15, С.309-310].

Д.С. Лихачев в своей статье «Повести о Николе Заразском» приходит к выводу о литературном характере данного памятника, состоящего из отдельных частей. Наиболее древними являются воинские повести (первая половина XIV века), а наиболее поздней (середина XVI века) - «одно из трафаретных церковных чудес» [11, C.236]. В XVII веке повести подверглись переработке в духе сближения с фольклором, что сказалось на достоверности изложенных в них сведений. Всего историк выделяет более 10 редакций Повестей о Николе Заразском [11, C.242-243].

В последнее десятилетие XX века и начале XXI века наблюдается всплеск интереса к истории Зарайска. Главную роль в этом сыграли краеведы и, особенно, настоящий подвижник изучения своего края В.И. Полянчев. Было проведено несколько конференций и выпущено 3 сборника историко-краеведческого альманаха «Евстафий», названного так по имени легендарного автора Цикла повестей о перенесении образа Николы Заразского. Такая активность общества Зарайских краеведов и сотрудников государственного музея-заповедника «Зарайский Кремль» подогрела интерес к истории города Зарайска со стороны профессиональных историков.

В 1993 году выходит статья И.А. Лобаковой, в которой она подвергла критике идеи В.Л. Комаровича, А. Поппэ о 
неисторичности «Повести о разорении Рязани Батыем», входящей в цикл «Повестей о Николе Заразском» [12, С.49]. Развивая идеи Д.С. Лихачева о разновременном создании памятников, входящих в цикл «Повестей...», И.А. Лобакова выдвигает в качестве связующей их всех нити идею «великой конечной погибели». Именно это стремление автора Повести о разорении Рязани Батыем, по ее мысли, и является причиной всех несостывок в тексте. Эта же идея связывает между собой и весь цикл «Повестей...» [12, С.49-52].

В декабре 1998 года в Зарайске состоялась научно-богословская конференция: «Зарайские мученики - князь Феодор, княгиня Евпраксия и их сын Иоанн». Она продемонстрировала возрождающийся интерес к истории города Зарайска. Материалы конференции предваряются приветственными словами Ювеналия, Митрополита Крутицкого и Коломенского и Д.С. Лихачева, содержат тексты цикла Повестей о Николе Заразском. Конференция пробудила интерес у профессиональных историков к истории города.

В своей статье «Повести о Николе Заразском» Д.С. Лихачев дает хронологический анализ возникновения отдельных элементов Повестей. Особенно подробно он останавливается на «Повести о разорении Рязани Батыем», прослеживая характер происходивших с ней изменений. Временем создания последней автор считает XIV век. В целом Лихачев Д.С. отмечает литературный характер Повестей.

В заочную полемику с Лихачевым Д.С. вступает Амелькин А.О. Проанализировав цикл Повестей о Николе Заразском, он приходит к выводу о собрании разновременных литературных памятников, большинство из которых было создано в начале XVI века [2, С.96].

И.Г. Добродомов в своей статье «Топоним Зарайск» провел анализ названия города с двух направлений: топографического и филологического. Одновременно был проведен и анализ исследований на тему происхождения города. С использованием примеров было убедительно доказана несостоятельность теорий, основанных на Повести о Николе Заразском и лингвистическом анализе. Единственно верной версией следует считать происхождение топонима Зарайск от урочища Заразы [6, C.49]. Проследив изменения в названии города Зарайска, автор пришел к выводу, что двойственность названия в XVI веке говорит о новизне города, о том, что название пока не устоялось [6, C.54].

В своей статье А.Б. Мазуров поднимает проблему достоверности событий, изложенных в «Коломенском эпизоде» Повестей о Николе Заразском. Автор провел хронологический и топографический анализ изложенных сведений. Было выделено два эпизода, написанных разными авторами - свидетелями событий, в Коломне (первый) и в Зарайске (второй). Первоначально записи были сделаны в 1517 году, а окончательно оформлены в 1528-1530 годах, как обоснование строительства каменного Зарайского кремля [13, С.71].

В 2001 году В.И Полянчев издает «Зарайскую летопись», в которой он постарался изложить историю города Зарайска, соединив все имеющиеся сведения. К сожалению, работа носит в большей степени научнопопулярный характер и некритично подходит к ранним источникам. Сведения из них принимаются автором как абсолютно подлинные. Имеющиеся «пустые места» домысливаются автором. Несомненным достоинством работы является, то что это по-настоящему первая работа, объединяющая всю историю Зарайска. Автор проделал огромную работу оп изучению источников, но не критичный характер их использования, особенно по раннему периоду (до XVI века), нивелирует все достоинства.

В 2001-2012 годах издается Альманах Зарайского исторического общества «Евстафий». Первый номер выходит в 2001 году, второй - в 2003, а третий - в 2012. В альманахе издавали свои работы члены Зарайского исторического общества по различной тематике, печатались выдержки из работ историков, велась активная просветительская работа. Третий номер был полностью посвящен событиям Смутного времени и особой роли воеводы Зарайска Д.М. Пожарского.

Интересной с исторической точки зрения является автобиографичная статья В.И. Полянчева «Когда и как Зарайск стал Зарайском». В ней автор подробно изложил хронологию своих изысканий по вопросу о дате основания Зарайска. Интерес представляет приводимая автором переписка с Б.А. Рыбаковым, А.Н. Сахаровым, В.А. Кучкиным [18, С.117-119].

А.Г. Глуховым, а затем и В.И. Полянчевым активно отстаивалась идея о существовании в Зарайске при Никольском соборе собственной книжной мастерской. Они считали, что в 1401 году из рук ее мастеров вышло «Зарайское Евангелие».

По мнению, Л.И. Максимовой к началу XVI века на месте Зарайска находилось два монастыря: Круглый Троицкий монастырь и Николо-Зарайский со своими небольшими слободами и вотчины рязанских бояр Глебовых, Коркодымовых, Павловых [14, С.155].

Вершиной научного изучения истории города становится вышедший в 2002 году двухтомный сборник статей «Зарайск». Первый том «Исторические реалии и легенды» был издан под эгидой Института Российской истории РАН и включал в себя работы виднейших российских историков. Второй том «Проблемы и перспек- 
тивы духовного и культурного развития» был издан по итогам одноименной конференции и объединил работы профессиональных историков и краеведов.

В первый том вошли уже упоминавшиеся выше работы И.Е. Зайцевой «Средневековый культурный слой Зарайска» и И.Ю. Стрикалова. «Керамика Зарайска», которые подвели итог археологическим изысканиям на территории города Зарайска.

В.А. Кучкин в своей статье «Ранняя история города Зарайска и проблема ее источников» подробно анализирует историографию по вопросу определения даты основания города и летописные источники. По его мнению, в историографии XIX века сложились две основные версии относительно времени возникновения города Зарайска: одни считали временем возникновения XV в., а другие - XIII в. Правда, существовала идея считать отправной точкой 1531 г., но она не получила распространения [10, С.46]. Анализируя отрывок из Никоновской летописи под 1146/1147 гг., сообщающий о походе Святослава Ольговича, Кучкин В.А. приходит к выводу о том, что это более поздняя вставка XVI века, вызванная стремлением обосновать претензии московского великого князя на спорные с Литвой территории [10, С.89-94]. Также сомнению подвергаются и сведения, содержащиеся в цикле Повестей о Николе Заразском: ни в одном летописном своде нет упоминаний о Федоре Юрьевиче. Кроме того, территория, на которой располагался Зарайск принадлежала Пронским князьям, а, следовательно, здесь не могло находиться владений сына рязанского князя [10, С.107].

Б.М. Клосс посвятил свое внимание вопросу о времени создания Повести о Николе Заразском и пришел к выводу, что данное литературное произведение было написано в одно время и одним автором в 1560 году. Все его части объединены общей идеей прославления местных святынь, и поэтому к ее созданию причастен клир Никольской церкви, а автором следует считать протопопа Ивана Вислоуха [8, С.172-176].

Я.Е. Водарский определяет время возникновения Зарайска как населенного пункта 1509-1510 годами, а временем основания города считает 1597 год [4, С.178-233].

К.А. Аверьянов, проведя анализ имеющихся данных, доказывает, что в XIV - XV веках на территории города Зарайска населенного пункта не было [1, С.72]. Документы, указывающие на село или погост при храме Николы Заразского появляются только в конце XV - начале XVI вв. При этом точно установить, о чем идет речь, не представляется возможным. По мнению ученого, строительство кремля в Зарайске завершилось в 1532 году, а не в
1531. Использование же разных наименований города свидетельствует о его молодости [1, С.94].

Постепенно инициатива в изучении истории Зарайска переходит к работникам музея-заповедника «Зарайский Кремль».

В 2011 году выходит сборник научных статей сотрудников музея «Зарайский Кремль». Наибольший для нас интерес в нем представляют работы Л.И. Максимовой, продолжившей разрабатывать темы городской застройки Зарайска в XVI - XVIII веках и истории монастырей (первые работы по ним появились в 2001 и 2002 годах); А.А. Румянцевой, посвященная историко-архитектурному анализу Зарайского Кремля.

В 2015 году в журнале «Подмосковный летописец» выходят статьи К.В Кондратьева и И.Городецкой, посвященные развитию города и роли Кремля. В 2017 году эти же авторы выпускают переработанные статьи в сборнике статей «Зарайск и его твердыня». Статьи носят обобщающе-информационный характер.

Хронологически можно выделить два периода в развитии историографии Заарйска в XX-XXI в.в..

Во время советского периода основное внимание историков сместилось с определения даты основания Зарайска на анализ основных источников. Анализу подверглись сообщение Никоновской летописи и цикл повестей о Николе Зарайском. Кроме этого, серьезное внимание было уделено археологическому изучению Поочья. К сожалению, в самом Зарайске серьезных археологических работ не проводилось.

Современный (с 1990-х гг. до наших дней) период включает в себя последнюю четверть XX - начало XXI века. В обсуждение уже поднимавшихся ранее и поставленных вновь проблем активно включаются профессиональные историки, краеведы и сотрудники музея-заповедника «Зарайский Кремль». В Зарайске создается историческое общество, проводятся конференции, выпускаются сборники статей. При этом по вопросу об основании города наблюдается серьезная дискуссия между краеведами и профессиональными историками, так и не пришедшими к единому мнению. Первоначально инициатива находилась в руках краеведов, но постепенно перешла в руки историков, а затем к сотрудникам музея.

Сложилась уникальная ситуация. История небольшого подмосковного города Зарайск вызывала к себе интерес со стороны краеведов и академических историков. При этом итоги так и не были подведены, и ясности в поднимаемых вопросах не наступило. 


\section{ЛИТЕРАТУРА}

1. Аверьянов К.А. Зарайский край XIV - первой трети XVI века. // Зарайск. Т.2: Проблемы и перспективы духовного и культурного развития. М.: Древнехранилище, 2002. С. $71-96$.

2. Амелькин А.О. 0 времени создания и литературной истории цикла Повестей о Николе Заразском. // Научно-богословская конференция «Зарайские мученики - князь Феодор, княгиня Евпраксия и их сын Иоанн». М.: «Новый век», 1998. С. 73 - 100.

3. Антонова В.И. Московская икона начала XIV века из Киева и «Повесть о Николе Зарайском» // ТОДРЛ. М., Л.: Изд-во АН СССР, 1957. Т. 13. С. 375 - 392.

4. Водарский Я.Е. Зарайск: тайна рождения. // Зарайск. Т.1: Исторические реалии и легенды. М.: Древнехранилище, 2002. С. 178 - 253.

5. Городенцева И. Кремль - исток Зарайска. // Подмосковный летописец. 2015. - № 4 (46). С. 70 - 75.

6. Добродомов И.Г. Топоним Зарайск. //Научно-богословская конференция «Зарайские мученики - князь Феодор, княгиня Евпраксия и их сын Иоанн». М.: «Новый век», 1998. С. $44-56$.

7. Зайцева И.Е. Средневековый культурный слой Зарайска. // Зарайск. Т.1: Исторические реалии и легенды. М.: Древнехранилище, 2002. С. 7 - 22.

8. Клосс Б.М. История создания Повести о Николе Заразском. // Зарайск. Т.1: Исторические реалии и легенды. М.: Древнехранилище, 2002. С. 114 - 177.

9. Кондратьев К. «Город обстроен правильно»: Зарисовки к истории города Зарайска от его истока до начала XX века. // Подмосковный летописец. 2015. № 4 (46). С. $36-41$.

10. Кучкин В.А. Ранняя история города Зарайска и проблема ее источников. // Зарайск. Т.1: Исторические реалии и легенды. М.: Древнехранилище, 2002. C. $40-113$.

11. Лихачев Д.С. Повести о Николе Заразском. // Исследования по древнерусской литературе. Л.: Наука, 1986. С. 235 - 257.

12. Лобакова И.А. Проблемы соотношения старших редакций «Повести о разорении Рязани Батыем». // ТОДРЛ. СПБ., 1993. Т. 46. С. 36 - 52.

13. Мазуров А.Б. «Коломенский эпизод» цикла Повестей о перенесении чудотворного образа Николая Заразского как исторический источник. // Научно-богословская конференция «Зарайские мученики - князь Феодор, княгиня Евпраксия и их сын Иоанн». М.: «Новый век», 1998. С. 57 - 72.

14. Максимова Л.И. Версия о монастыре // Евстафий. Альманах Зарайского исторического общества. 2001. № 1. С. 145 - 155.

15. Монгайт А.Л. Рязанская земля. М.: Издательство Академии Наук СССР, 1961. 400 с.

16. Насонов А.Н. «Русская земля» и образование территории древнерусского государства. Монголы и Русь. СПб.: Издательство «Наука», 2006.415 с.

17. Перлов И. Зарайские укрепления XVI - XVII вв. //Труды Зарайского Краевого Музея, вып. 1. Зарайск, 1927. 49 с.

18. Полянчев В.И. Когда и как Зарайск стал Зарайском //Евстафий. Альманах Зарайского исторического общества. 2001. № 1. С. 113 - 138.

19. Стрикалов И.Ю. Керамика Зарайска. // Зарайск. Т.1: Исторические реалии и легенды. М.: Древнехранилище, 2002. С. 23 - 39.

20. Тихомиров М.Н. Список городов дальних и ближних. // Тихомиров М.Н. Русское летописание. М.: «Наука», 1979. С. 83 - 137.

(с) Родионов Александр Викторович (1979rav@mail.ru).

Журнал «Современная наука: актуальные проблемы теории и практики»

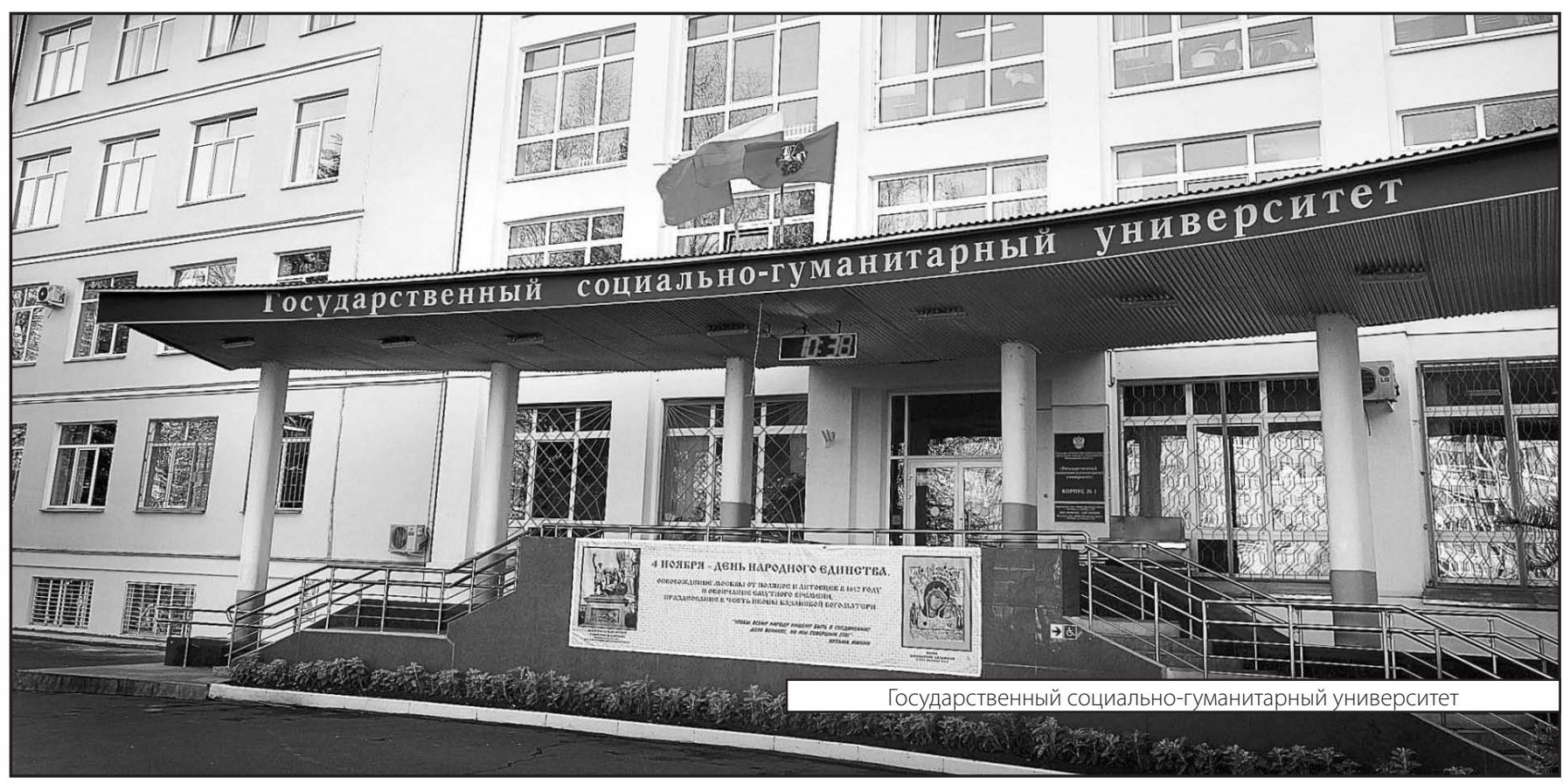

